\title{
Green Synthesis and Antibacterial Activity Studies of Silver Nanoparticles from the Aqueous Extracts of Euphorbia hirta
}

\author{
Bennet Rohan D. ${ }^{1}$, Raji P. ${ }^{1}$ (D), Divya Kumar M. ${ }^{1}$, Ratna Geethika Gandham ${ }^{1}$, \\ Kripu Sharma V. ${ }^{1}$, Keerthana D. ${ }^{1}$, Karishma S. ${ }^{1}$, Antony V. Samrot ${ }^{2 *}$ (D), Iyappan Petchi ${ }^{2}$, \\ Thirumurugan R. ${ }^{3}$, Sajna Keeyari Purayil' ${ }^{2}$, Paulraj Ponnaiah ${ }^{2}$, Jenifer Selvarani A. ${ }^{1}$ (D) \\ and Prakash P. ${ }^{1}$
}

\begin{abstract}
${ }^{1}$ Department of Biotechnology, Sathyabama Institute of Science and Technology, Jeppiaar Nagar, Rajiv Gandhi Salai, Chennai - 600 119, Tamil Nadu, India. ${ }^{2}$ Department of Biomedical Sciences, Faculty of Medicine and Biomedical Sciences, MAHSA University, Jalan SP2, Bandar Saujana Putra, 42610 Jenjarom, Selangor, Malaysia. ${ }^{3}$ Department of Transfusion Medicine, JIPMER, Puducherry - 605 006, India.
\end{abstract}

\begin{abstract}
The aqueous extracts of Euphorbia hirta was used to synthesise silver nanoparticles using bioreduction method. The nanoparticles were characterised by UV Vis spectroscopic analysis, SEM, EDX, AFM, XRD analysis. The silver nanoparticles were also tested for antibacterial activity in Pseudomonas aeruginosa and Bacillus subtilis. The minimum inhibitory concentration for the synthesised nano particles were also tested against the two bacterial species for the least concentration of $0.5 \mu \mathrm{g} / \mathrm{mL}$. The swarming motility assay and protein leakage assay was also tested for the nanoparticle. The silver nanoparticles were found to be much effective.
\end{abstract}

Keywords: Silver nanoparticles, Antibacterial activity, MIC, Protein leakage assay, Euphorbia hirta

\begin{abstract}
*Correspondence: antonysamrot@gmail.com
(Received: November 28, 2019; accepted: March 03, 2020)

Citation: Bennet Rohan D., Raji P., Divya Kumar M., Ratna Geethika Gandham, Kripu Sharma V., Keerthana D., Karishma S., Antony V. Samrot, Iyappan Petchi, Thirumurugan R., Sajna Keeyari Purayil, Paulraj Ponnaiah, Jenifer Selvarani A. and Prakash P., Green Synthesis and Antibacterial Activity Studies of Silver Nanoparticles from the Aqueous Extracts of Euphorbia hirta, J. Pure Appl. Microbiol., 2020; 14(1): 301-306. https://doi.org/10.22207/JPAM.14.1.31

(C) The Author(s) 2020. Open Access. This article is distributed under the terms of the Creative Commons Attribution 4.0 International License which permits unrestricted use, sharing, distribution, and reproduction in any medium, provided you give appropriate credit to the original author(s) and the source, provide a link to the Creative Commons license, and indicate if changes were made.
\end{abstract}




\section{INTRODUCTION}

The tropical location of the Indian subcontinent has offered us with enormous species of medicinal plants of over 2500 species used for curing various ailments ${ }^{1}$. Euphorbia hirta is one such plant from the family Euphorbiaceae used as a herb for treating respiratory disorders, dysentery, jaundice, pimples, gonorrhea, digestive problems, tumors etc., These annual plants have thin purple coloured stem growing upto a height of $40 \mathrm{~cm}$ bearing fruit of $1-2 \mathrm{~mm}$. The plants have elliptical leaves of 1-2.5 cm long and oppositely arranged ${ }^{2,3}$. Ayurvedic medicine uses the decoction of the fresh plant as gargles whereas the dry leaf decoctions are applied for skin disorders. Roots are of great value in treating snake bites and also orally consumed by nursing mothers ${ }^{4}$. This slender plant spreads out well in open space, grasslands and is frequently seen in tropical countries like Southeast Asia, China, Philippines, Australia, Africa \& Malaysia ${ }^{5-7}$. Phytochemical studies have shown the presence of lignans, diterpene, taraxerol, pinoresinol, scopoletin, quercetin, kaempferol, luteolin and Gallic acid ${ }^{8-10}$. This plant is enriched with flavonoids that restrain microorganisms with antibiotic resistance at lower inhibitory concentrations $\mathrm{s}^{11,12}$. Exploring of plant derives nanoparticles is extensively studied for its interesting and enormous bioactive potential ${ }^{13,14}$. Our present studies focus on the synthesis of silver nanoparticles from the leaf extracts of Euphorbia hirta and understand the antibacterial activity of the nanoparticles against Pseudomonas aeruginosa and Bacillus subtilis.

\section{MATERIALS AND METHODS \\ Preparation of plant extracts}

The plant material was collected from Chennai and authenticated by Dr. P Jayaraman, Director, Plant Anatomy Research Center, from Chennai. The aqueous extracts of Euphorbia hirta was prepared by boiling $20 \mathrm{~g}$ of powdered leaf material in distilled water and the filtrate was used. Synthesis of Silver nanoparticle

The nano particle synthesis of the plant material was carried out by treating the aqueous extract with $3 \mathrm{mM}$ silver nitrate with dark incubation for $24 \mathrm{~h}$. The reduction was observed by a change in colour from pallid yellow to dark brown. The content was then centrifuged at 5000 $\mathrm{g}$ and the pellet lyophilized and stored at $4^{\circ} \mathrm{C}^{15}$. Characterization of silver nanoparticles

The characteristics of the nanoparticle was subjected to spectroscopic analysis by exposing them in UV-Visible spectroscopy (UV - 1800 Shimadzu, Japan) and verifying the absorbance when exposed to radiations in 200 to $800 \mathrm{~nm}$. Spectral analysis was also checked in FTIR for a range $4000-400 \mathrm{~cm}^{-1}$ (Alpha Bruker optic Gmbh instrument). The nanoparticle with the specific absorbance was validated for its size by Scanning Electron Microscopy (Zeiss, GeminiSem) and their elemental composition by EDX spectrometry. The nanoparticles were viewed under for its crystallinity by analysing them in $20^{\circ}-$ $80^{\circ}$ at $2 \theta$ angles in X-ray diffraction (XRD) unit.

Antibacterial activity by agar well diffusion method

The ability of the nanoparticle to interact with cells was studied by antibacterial activity against the test organism Pseudomonas aeruginosa and Bacillus subtilis. The results were compared to a positive control, Erythromycin ${ }^{16}$.

Minimum inhibitory concentration of the silver nanoparticle

Further the minimum concentration to interact with the test organisms, Pseudomonas aeruginosa and Bacillus subtilis was carried out through micro dilution method with the concentration range $(0.25$ to $2 \mu \mathrm{g} / \mathrm{mL})$.

Swarming motility

The microorganisms Pseudomonas aeruginosa and Bacillus subtilis were co-cultured in a medium supplemented with silver nanoparticles $(0.5 \mu \mathrm{g} / \mathrm{mL})$ to assess the effect of motility in microbes $^{17}$.

Protein leakage assay

The interaction of the silver nanoparticles on the biological membranes was checked by protein leakage assay against Pseudomonas aeruginosa and Bacillus subtilis ${ }^{18}$.

\section{RESULTS AND DISCUSSION \\ Characterization of silver nanoparticles}

Bio reduction potential of the aqueous extracts of Euphorbia hirta to silver nano particles were noted initially by the change in colour of the solution to dark brown after a contact period of 
$24 \mathrm{~h}$. However, validation of the nano synthesis was done by various instrumental analysis, primarily confirming by UV- Visible spectrometry which had spectral peaks near 300-400 nm (Fig. 1 ) indicative of silver nanoparticles ${ }^{19}$. The spectral data of the transmittance analysis in the FTIR had peaks at $1402 \mathrm{~cm}^{-1}, 1324 \mathrm{~cm}^{-1}$ denotes the presence of $\mathrm{CH}_{3}$ and $\mathrm{CH}_{2}$ bending, $1201 \mathrm{~cm}^{-1}$ (Fig. 2) and an amide bond at $1600 \mathrm{~cm}^{-120}$. The size of the nanoparticles in scanning electron microscopic studies was found to be spherical particles in the range $50-80 \mathrm{~nm}$ (Fig. 3) which gave a strong peak at $3 \mathrm{keV}$ in EDX analysis corroborating the presence of elemental silver (Fig. 4). Diffraction points of $38^{\circ}, 44.5^{\circ}, 64.81^{\circ}, 77.43^{\circ}$ corresponding to (111), (200), (220), (311) planes confirmed the presence of crystalline structures in XRD (Fig. 5) analysis ${ }^{21}$. Antibacterial activity of silver nanoparticles

The antibacterial activity of the silver nanoparticles against the test organisms Grampositive (Bacillus subtilis) and Gram-negative (Pseudomonas aeruginosa) organisms showed

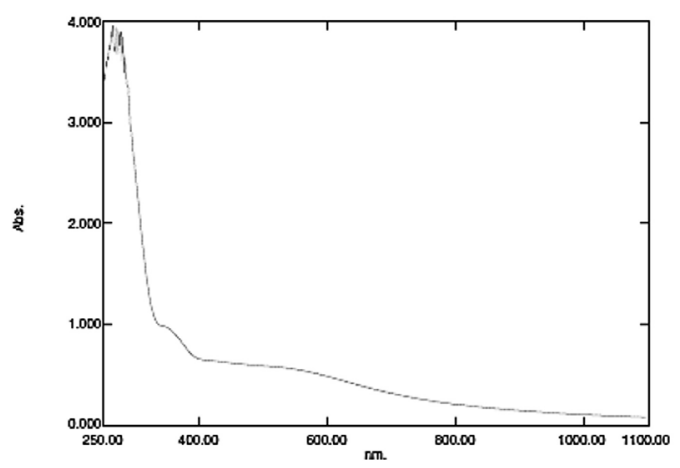

Fig. 1. UV Visible spectroscopy of crude silver nanoparticles

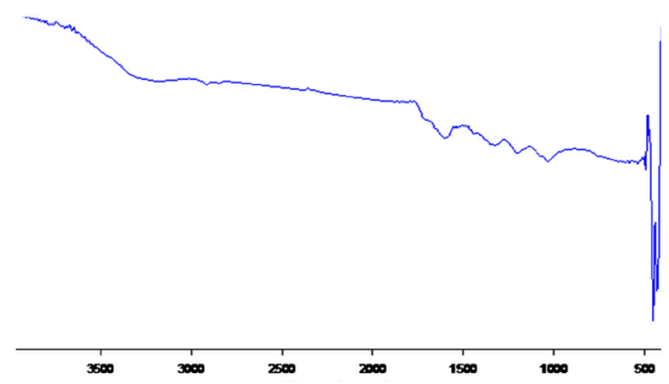

Fig. 2. FTIR spectroscopy of crude silver nanoparticles effective inhibition in growth (Fig. 6). Bactericidal activity was found for the least study concentration of $2 \mu \mathrm{g}$ itself (Table 1 ). The potency of the antibacterial effect increased with the increase in concentration of the nanoparticle with the highest of $1.8 \mathrm{~cm}$ for Pseudomonas aeruginosa at $16 \mu \mathrm{g}$ followed by $1.7 \mathrm{~cm}$ for $8 \mu \mathrm{g}$ concentration. $0.3 \mathrm{~cm}$ of zone of inhibition was lowest for $2 \mu \mathrm{g}$ concentration against Bacillus subtilis. Further the study was conducted to assess the minimum concentration necessary to bring about the death of the organism, hence a study range of $0.25(\mu \mathrm{g} / \mathrm{mL})$ to $2.0(\mu \mathrm{g} / \mathrm{mL})$ was taken. The minimum concentration to make the organism susceptible was $0.25 \mu \mathrm{g}$ for Bacillus subtilis, $0.5 \mu \mathrm{g}$ for Pseudomonas aeruginosa (Table 2). The least concentrations of the nanoparticles conferring antibacterial property of silver nanoparticles can be utilised in various industrial processes such as tanning of leather, coating agent of medical devices, as drug loading agents and removal of heavy metals ${ }^{22,23}$.

Table 1. Antibacterial activity of crude silver nanoparticles against the micro organisms

\begin{tabular}{lcc}
\hline Concen. $(\mu \mathrm{g})$ & \multicolumn{2}{c}{ Zone of Inhibition $(\mathrm{cm})$} \\
\cline { 2 - 3 } & $\begin{array}{c}\text { Pseudomonas } \\
\text { aeruginosa }\end{array}$ & $\begin{array}{c}\text { Bacillus } \\
\text { subtilis }\end{array}$ \\
\hline 2 & 0.5 & 0.3 \\
4 & 1.5 & 0.4 \\
8 & 1.7 & 0.4 \\
16 & 1.8 & 0.4 \\
Positive control & 0.4 & 1.4 \\
(Erythromycin) & & \\
Negative control & - & - \\
(Solvent) & & \\
\hline
\end{tabular}

Table 2. Minimum Inhibitory Concentration (MIC) of crude silver nanoparticle

\begin{tabular}{llllll}
\hline \multirow{2}{*}{ No } & Bacterial species & \multicolumn{4}{c}{ Concentration $(\mu \mathrm{g} / \mathrm{mL})$} \\
\cline { 3 - 6 } & & 2 & 1 & 0.5 & 0.25 \\
\hline 1 & $\begin{array}{l}\text { Bacillus subtilis } \\
2\end{array}$ & + & + & + & + \\
& $\begin{array}{l}\text { Pseudomonas } \\
\text { aeruginosa }\end{array}$ & + & + & + & - \\
\hline
\end{tabular}

+ indicates no growth of organisms 


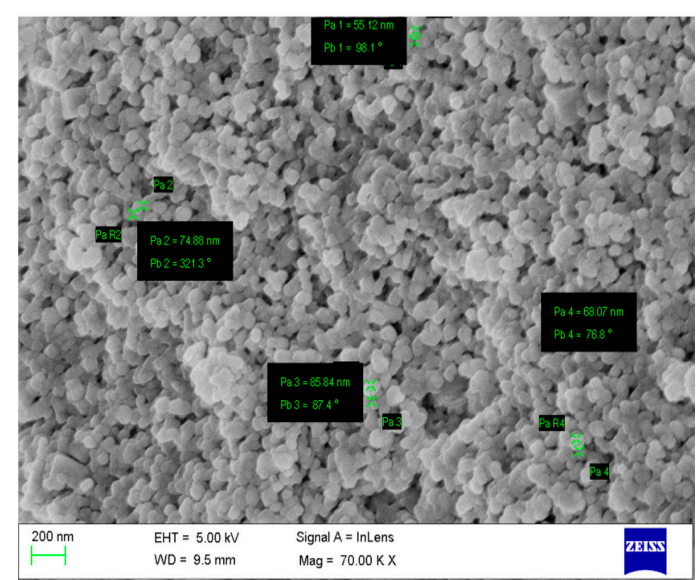

Fig. 3. Scanning Electron Microscopy (SEM) of crude silver nanoparticles

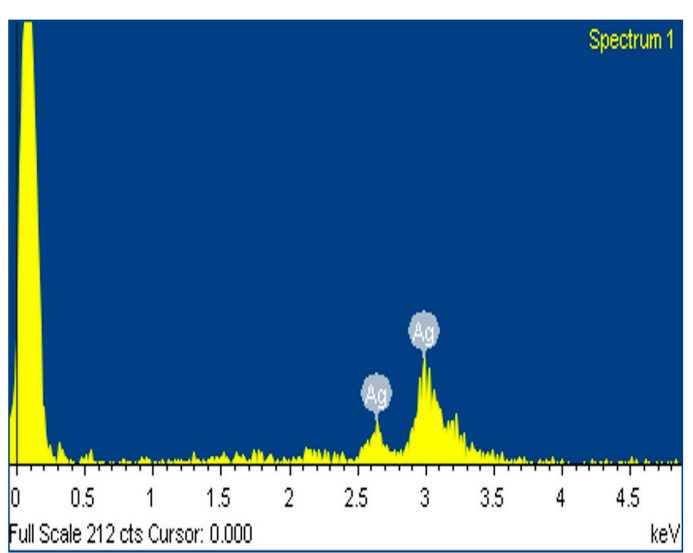

Fig. 4. Energy Dispersive X-Ray spectroscopy (EDX) of crude silver nanoparticles

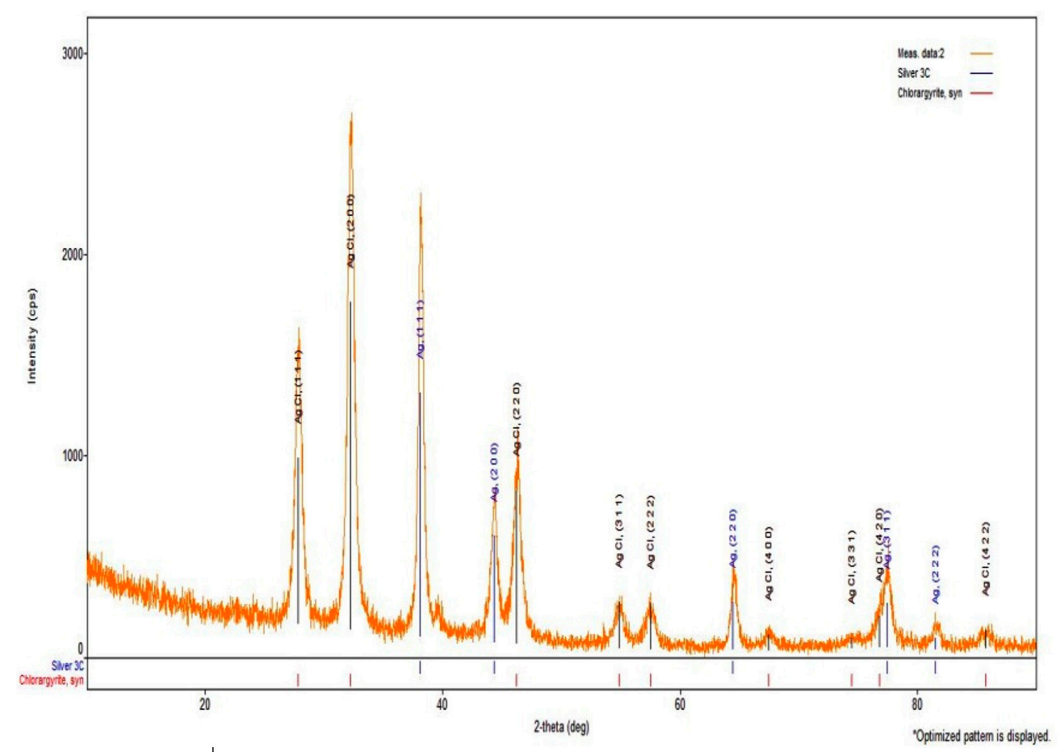

Fig. 5. X-Ray Powder Diffraction (XRD) of crude silver nanoparticles

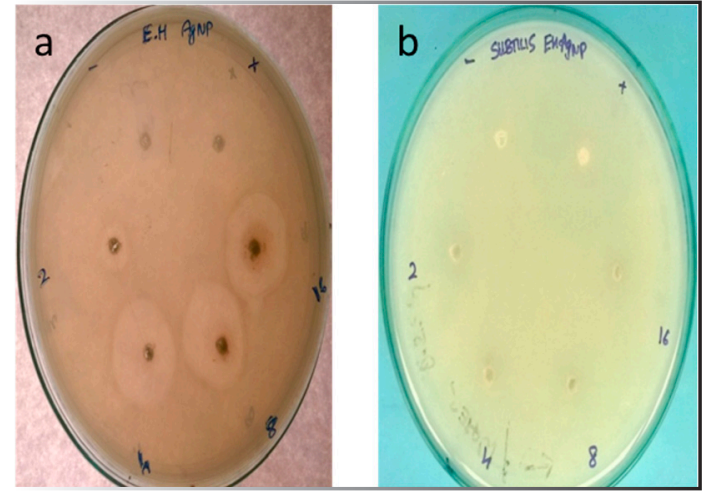

Fig. 6. Antibacterial activity of crude silver nanoparticles against a) Pseudomonas aeruginosa b) Bacillus subtilis

\section{Swarming motility and Protein leakage assay of silver nanoparticles}

The silver nanoparticle inhibited the motility of both Bacillus subtilis and $P$. aeruginosa. Moderate results were obtained for Bacillus subtilis compared to that of the other (Fig. 7). The penetration of the nanoparticles into the membrane was evaluated by protein leakage assay. The silver nanoparticles destabilised the membranes of $P$. aeruginosa than the Bacillus subtilis. Marthai et al ${ }^{18}$ also reported the tendency of silver nanoparticles to make the cell wall to break and leads to protein leakage. 
a

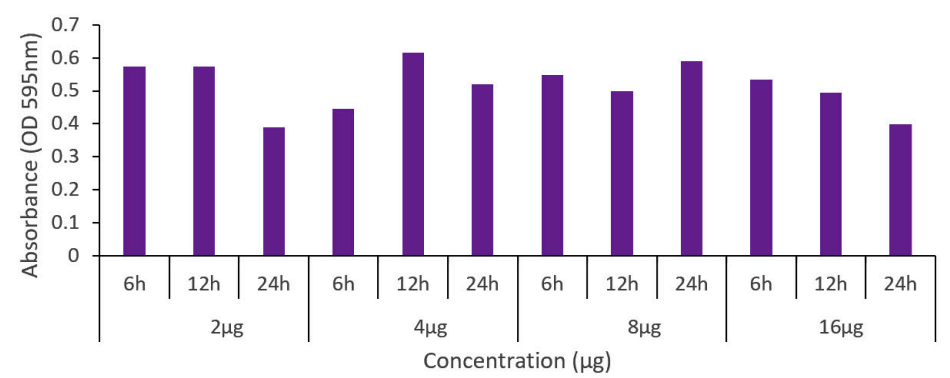

b

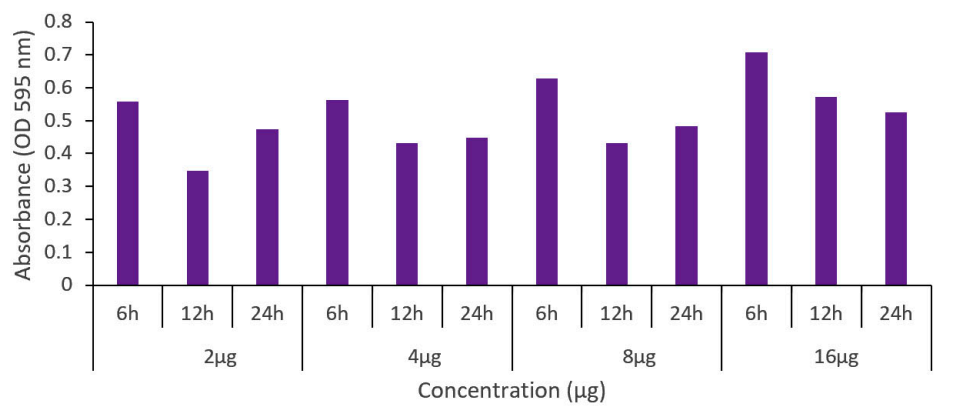

Fig. 7. Protein leakage assay of crude silver nanoparticles against Pseudomonas aeruginosa and b) Bacillus subtilis
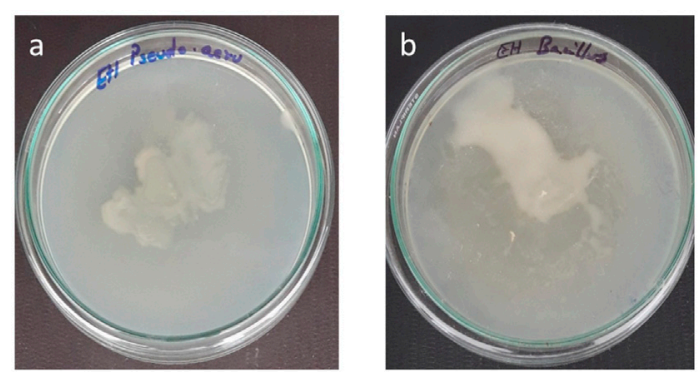

Fig. 8. Swarming motility of crude silver nanoparticle against a) Pseudomonas aeruginosa b) Bacillus subtilis

\section{CONCLUSION}

In this study, silver nanoparticles were produced using the crude extract of $E$. hirta, characterized both spectroscopically and microscopically. It was producing crystalline silver nanoparticles of size around 50 to $80 \mathrm{~nm}$ and it was possessing a good antibacterial activity against $P$. aeruginosa and $B$. subtilis.

\section{ACKNOWLEDGEMENTS}

All authors acknowledge, Management, Sathyabama Institute of Science and Technology for providing the lab.

\section{CONFLICT OF INTEREST}

The authors declare that there is no conflict of interest.

\section{FUNDING}

None.

\section{AUTHORS' CONTRIBUTION}

All the authors have made direct contribution on idea creation, research work and editing of the manuscript.

\section{DATA AVAILABILITY}

Not applicable.

\section{ETHICS STATEMENT}

No animal or human samples involved in this study, hence it does not require ethical clearance.

\section{REFERENCES}

1. Prajapati ND, Purohit SS, Sharma AK, Kumar T. Handbook of Medicinal Plants. Agarbios; Jodhpur, India, 2003. 
2. Kumar S, Malhotra R, Kumar D. Euphorbia hirta: Its chemistry, traditional and medicinal uses, and pharmacological activities. Pharmacogn Rev. 2010; 4(7): 58-61. https://doi.org/10.4103/09737847.65327

3. Singh B, Dutt N, Kumar D, Singh S, Mahajan R. Taxonomy, ethnobotany and antimicrobial activity of Croton bonplandianum, Euphorbia hirta and Phyllanthus fraternus. Journal of Advances in Developmental Research. 2011; 2(1): 21-29.

4. Williamson EM. Major Herbs of Ayurveda. Churchill Livingstone, China, 2002.

5. Rajeh MAB, Zuraini Z, Sasidharan S, Latha LY, Amutha S. Assessment of Euphorbia hirta L. leaf, flower, stem and root extracts for their antibacterial and antifungal activity and brine shrimp lethality. Molecules, 2010; 15(9): 6008-6018. https://doi.org/10.3390/ molecules 15096008

6. Kausar J, Muthumani D, Hedina A, Anand V. Review of the phytochemical and pharmacological activities of Euphorbia hirta Linn. Pharmacognosy Journal, 2016; 8(4). https://doi.org/10.5530/pj.2016.4.2

7. Huang L, Chen S, Yang M. Euphorbia hirta (Feiyangcao): A review on its ethnopharmacology, phytochemistry and pharmacology. J. Med. Plant Res., 2012; 6(39): 5176-5185. https://doi.org/10.5897/JMPR12.206

8. Li E, Liu K, Zang $M$, Zhang $X$, Jiang $H$, Zhou H, Wang D, Liu J, Hu Y, Wu Y. Chemical constituents from Euphorbia hirta. Biochem Syst Ecol., 2015; 62: 204-207. https:// doi.org/10.1016/j.bse.2015.09.007

9. Liu H, Zhu G, Fan Y, Du Y, Lan M, Xu Y, Zhu W. Natural Products Research in China From 2015 to 2016. Front Chem., 2018; 6: 45. https://doi.org/10.3389/ fchem.2018.00045

10. Wu Y, Qu W, Geng D, Liang JY, Luo YL. Phenols and flavonoids from the aerial part of Euphorbia hirta. Chin J Nat Med., 2012; 10(1): 40-42. https://doi. org/10.1016/S1875-5364(12)60009-0

11. Singh G, Kumar P. Phytochemical study and screening for antimicrobial activity of flavonoids of Euphorbia hirta. Int J App Basic Med Res., 2013; 3(2): 111. https:// doi.org/10.4103/2229-516X.117082

12. Saravanan R, Dhachinamoorthi D, Senthilkumar K, Srilakshmi M, Sri TD. Antibacterial activity of Euphorbia hirta extracts. International Journal of Research in Ayurveda \& Pharmacy, 2012; 3(3).

13. Samrot AV, Shobana N, Jenna R. Antibacterial and Antioxidant Activity of Different Staged Ripened Fruit of Capsicum annuum and Its Green Synthesized Silver Nanoparticles. BioNanoScience, 2018; 8: 632-646. https://doi.org/10.1007/s12668-018-0521-8

14. Samrot AV, Raji P, Selvarani AJ, Nishanthini P. Antibacterial activity of some edible fruits and its green synthesized silver nanoparticles against uropathogenPseudomonas aeruginosa SU 18. Biocatalysis and agricultural biotechnology, 2018; 16: 253-270. https:// doi.org/10.1016/j.bcab.2018.08.014

15. Samrot AV, Silky Ignatious VC, Raji P, SaiPriya C, Selvarani AJ. Bioactivity Studies of Datura metel, Aegle marmelos, Annona reticulata and Saraca indica and their Green Synthesized Silver Nanoparticle. J Pure Appl Microbiol., 2019; 13(1): 329-338. https://doi. org/10.22207/JPAM.13.1.36

16. Raji P, Samrot AV, Dharani D, Alexander B. In vitro and In silico Approaches to Study the Bioactivity of Citrus limon Leaf Extracts. J Young Pharm., 2017; 9(2): 290295. https://doi.org/10.5530/jyp.2017.9.57

17. Raji P, Samrot AV, Rohan DB, Kumar DP, Gandham RG, Sharma VK, Keerthana D. Extraction, Characterization and Invitro Bioactivity Evaluation Of Alkaloids, Flavonoids, Saponins And Tannins Of Cassia alata, Thespesia populnea, Euphorbia hirta and Wrightia tinctoria. Rasayan J. Chemistry. 2019; 12(1): 123-137. https://doi.org/10.31788/RJC.2019.1214054

18. Maruthai K, Vallayyachari K, Ravibalan T, Philip SA, Samrot AV, Muthuraj M. Antibacterial activity of the Silver Nanoparticles against Escherichia coli and Enterobacter sp. Progress in Bioscience and Bioengineering, 2017; 1(1): 29-35. https://doi. org/10.29269/pbb2017.v1i1.1

19. Renugadevi K, Aswini V, Raji P. Microwave Irradiation Assisted Synthesis of Silver Nanoparticle Using Leaf Extract of Baliospermum Montanum And Evaluation of Its Antimicrobial, Anticancer Potential Activity. Asian Journal of Pharmaceutical and Clinical Research, 2012; 5: 283-287.

20. Samrot AV, Suvedhaa B, Sahithya CS, Madankumar A. Purification and Utilization of Gum from Terminalia catappa L. for Synthesis of Curcumin Loaded Nanoparticle and Its In Vitro Bioactivity Studies. Journal of Cluster Science, 2018; 29: 989-1002. https:// doi.org/10.1007/s10876-018-1412-4

21. Samrot AV, Angalene JLA, Roshini SM, Stefi SM, Preethi R, Raji P, Kumar M, Paulraj P, Kumar SS. Purification, characterization and utilization of polysaccharide of Araucaria heterophylla gum for the synthesis of curcumin loaded nanocarrier. International Journal of Biological Macromolecules, 2019; 140. https://doi. org/10.1016/j.ijbiomac.2019.08.121

22. Raji P, Samrot AV, Bhavya KS, Sharan M, Priya S, Paulraj P. Greener Approach for Leather Tanning Using Less Chrome with Plant Tannins and Tannins Mediated Nanoparticles. Journal of Cluster Science, 2019; 30: 1533-1543. https://doi.org/10.1007/s10876-01901597-6

23. Samrot AV, Angalene JLA, Roshini SM, Raji P, Stefi SM, Preethi R, Selvarani AJ, Madankumar A. Bioactivity and Heavy Metal Removal Using Plant Gum Mediated Green Synthesized Silver Nanoparticles. Journal of Cluster Science, 2019; 30(6): 1599-1610. https://doi. org/10.1007/s10876-019-01602-y 